\title{
Effect of change in temperature on the tribological performance of micro surface textured DLC coating - CORRIGENDUM
}

\author{
Ahmed Arslan, Haji Hasan Masjuki, Mahendra Varman, Mohammad Abul Kalam, \\ Moinuddin Mohammed Quazi, and Mohammad Hossain Mosarof \\ doi: 10.1557/jmr.2016.12, Published by Materials Research Society with Cambridge University \\ Press, 28 January 2016.
}

In "Effect of change in temperature on the tribological performance of micro surface textured DLC coating," the author Ahmed Arslan should have been listed as Arslan Ahmed.

The authors and publisher regret this error.

\section{REFERENCE}

1. A. Ahmed, H.H. Masjuki, M. Varman, M.A. Kalam, M.M. Quazi, M.H. Mosarof. Effect of change in temperature on the tribological performance of micro surface textured DLC coating. J Mater. Res., doi: 10.1557/jmr.2016.12 (2016). 